\title{
Political correctness and political humour in Soviet Estonia and beyond $^{1}$
}

\author{
Maarja Lõhmus
}

\begin{abstract}
The article gives an overview of the history of censorship in Soviet Estonia, concentrating on the regulations that dictated the content of humorous texts and images from pre-1990s. The Estonian media communication developed in the interaction of two contradicting fields of influence: on the one hand, it was affected by the official institutional sphere, and on the other, by unofficial, reflexive and collective citizenship. During active Sovietisation in 1940s-1950s, people were deprived of any laughter and ambiguity. Public sphere was under the close scrutiny of political censorship. In the next two decades until the late $1980 \mathrm{~s}$, the reflexive and critical streams became more visible in the society. This was accompanied by publishing more and versatile humorous texts, the presence of humorous texts in printed press, and convergence of talented authors into a school of renowned humour journalists. Humour was institutionalised in both cultural and political sphere, and after 1987 it gained even new functions, becoming a forerunner for glasnost and an instrument of de-Sovietisation.

On the basis of the present study, we can claim that the presence of humour in journalism is an indicator of emotions in the public sphere.
\end{abstract}

Keywords: public sphere, journalism, humour, Estonia, censorship, Soviet period

\section{Introduction}

The article will discuss the role of humour in a totalitarian system. In these conditions, humour can be a useful tool for analysing people's reflections on the strains set by the system. In Soviet everyday life, humour was a medium for free self-expression in newspapers and other public texts, but at the same time it was a carefully guided, controlled and censored mode of communication. In

1 This paper has been supported by ESF (Estonian Scientific Foundation) grants no. 9121, 5845, 8329, and SF0180017s07. 
the course of this study, the foregrounding of humour and satire in the public texts of the Soviet period will be analysed.

When observing developments in the Estonian public sphere during the 20th century, the year 1940 seems to be the essential turning point. The 1940s was the decade when norms and regulations for public texts, based on the principles of a communist society back in 1917, were set forth by the Soviet authorities. The subsequent rhetoric started to evolve in the middle of the 1950s, embracing the local nuances specific to Estonia. As the appearance of humour in the media is closely related to the general developments in public texts, it is useful to list the stages of their formation in Soviet and post-Soviet Estonia. It is possible to name six distinct periods of political rhetoric from the beginning of the 1940 s to present times:

1. 1944-1955 Physical Sovietisation as well as Sovietised public texts dispersed the public sphere, adapting to the examples and myths set by Moscow and TASS; the control for political correctness was strong and punishments for breaching the norms were severe, ranging from physical assault to deportation, imprisonment, etc. The repertoire of political jokes was dictated by TASS and other official news agencies. Local political jokes or ambiguous texts were published by the Estonian journal "Looming” ('Creation').

2. 1955-1979 Mental Sovietisation introduced a divide between official and unofficial public texts. There were different norms and regulations, different degrees of canonisation and mythologisation for these two types of texts. Political humour developed quickly and was mostly channelled into the journal "Pikker" ('Thunder') and daily newspaper "Edasi" ('Forward'), cultural weekly "Sirp ja Vasar" ('Hammer and Sickle'). Professional journalists/humorists emerged.

3. 1980-1987 A violent period of mental Sovietisation was followed by constant warnings to and repressions on the journalists. Soviet texts and sign systems had become a playful part of the natural language and had lost their connection to real life and everyday discourse. Political humour prospered, and the efficiency of the audience to observe daily life and analyse texts to their tiniest nuances was high.

4. 1987-1991 Main keywords were the mental liberation of Estonia, followed by the adherence of public texts to real life, end of the Soviet mythology, and publishing of the texts written by the members of critical resistance. Political correctness disappeared and collective textual reflexivity was high. Political humour found its way into journalism.

5. 1991-2003 As Estonia was de facto and de jure liberated and its society totally restructured, a structural change in public texts and an alteration 
of the political sign system was required. This in turn brought about the introduction of a new discourse. Old Soviet political correctness was shifted into the category of humour itself, whereas new political correctness was being defined. Building a new normative sign system had moved textual political humour into the background. At the same time, picking up - amplifying - developing - travestying humour in the daily flow of public texts was quite usual.

6. 2004-Homogenisation of the Estonian public sphere with the European Union and European public sphere progresses slowly due to the lack of interest on the part of journalists. It has nevertheless brought about a discussion about the new global and European regulations on political correctness, and the principal attitude towards the notion is expressed through analysing and commenting on this particular issue. Informal and reflexive texts dominate the scene; formal texts came to be formulated close to the genre of "political humour".

\section{Foci of interest in Soviet Estonian media}

Estonian public texts have thus developed through distinctive periods, and the most controversial of these stages is the totalitarian period. According to sociological studies of the media, results show that in the 1960s the priorities of the auditorium were quite simple: $82-86 \%$ of the people wished to hear/read/ watch news about foreign issues in addition to listening to music (the preference of $82-86 \%$ of respondents), which refers to the fact that those areas were most probably poorly covered. It also shows that people wanted to possess a broader knowledge and understanding of the world (see Table 1). In the next period, throughout the 1970s and 80s, people leaned even more towards preferring music to everything else available through the media (86\%), growing to a record of $90 \%$ of media viewers during the years of the Singing revolution ${ }^{2}$ in 1989-1990. After becoming independent, the interest in music suddenly plunged to only $40 \%$. It is clear from this that music has carried an important role in the ideational system of the people living under a totalitarian regime

\footnotetext{
2 Singing Revolution - a label for the years of transformation from a totalitarian into a democratic society in Estonia (1988-1992) characterised by numerous spontaneous public events dedicated to discussion and singing. These gatherings broke free from the censorship and regulations of the totalitarian society and thus formed a solid incentive and backup for the changes. Some public events (e.g. the evening song festivals on the singing grounds in August 1988) played a leading role in the change. A general feature of the Singing Revolution was cheerfulness and humour towards the political situation and the feelings of helplessness.
} 
and Estonians' interest in music has covertly expressed their attitudes towards cultural politics on the whole.

Another equally clear indicator of the ideational system in the Estonian culture, side by side with music, has been the interest in humour and jokes. The need for this was especially high during the most rigid years of the totalitarian regime, during the 1970 s and the middle of 1980 s, when the public text was forced into a strict framework of orders and regulations. During that period it was only natural that in order to achieve an understanding of the society, and

Table 1. Thematic interests (\%) of the Estonian media audience (1966-2002).

\begin{tabular}{|l|l|l|l|l|l|l|l|l|}
\hline & $\mathbf{1 9 6 6}$ & $\mathbf{1 9 6 9}$ & $\mathbf{1 9 7 6}$ & $\mathbf{1 9 8 3}$ & $\mathbf{1 9 8 9}$ & $\mathbf{1 9 9 1}$ & $\mathbf{2 0 0 1}$ & $\mathbf{2 0 0 2}$ \\
\hline Music & 81.7 & 84.1 & 86.7 & 81.5 & 89.7 & 44 & & 53.4 \\
\hline Health & - & 75.9 & 78.5 & 70.1 & & 89.6 & 69.1 & 66.5 \\
\hline Foreign & 82.3 & 85.6 & 73.1 & 63.1 & & 85.9 & 55.3 & 59.6 \\
\hline Eport & 67 & 69.9 & 52.5 & 57.2 & 62.3 & 50.9 & 47.5 & 41 \\
\hline Rural life & 43.3 & 43.6 & 57.1 & 67.7 & & 75.1 & 40.1 & 31.3 \\
\hline Youth & & 83.6 & 72.2 & 63.7 & 79.5 & 57.2 & 59.6 & 40.3 \\
\hline Home & & 83.3 & 72.2 & 68.3 & 87 & 72.5 & & 56.6 \\
\hline Science & 65.9 & 69.1 & 39.0 & 31.6 & 31.2 & 18 & 39.5 & 39.5 \\
\hline Humour & & & 88.7 & 91.4 & 52.9 & 44 & 78.1 & 53.4 \\
\hline $\begin{array}{l}\text { Art/cinema/ } \\
\text { theatre }\end{array}$ & & 71 & 78.4 & 81.4 & 70.1 & 46.7 & 48.9 & 31.3 \\
\hline Fashion & & & 59.5 & 61.6 & & & & 25.5 \\
\hline Nature & & & 76.3 & 75.5 & & 86.8 & 63.2 & 49.9 \\
\hline Juridical & & & 78.1 & 67 & & 78.8 & 47.9 & 54.2 \\
\hline Technology & & & 58.4 & 54.8 & & & 39.5 & 29.5 \\
\hline Education & & & 60.6 & 77.6 & & 84.5 & 57.4 & 47.4 \\
\hline Literature & & & & 68 & & & 44.9 & 31.3 \\
\hline Crime & & & & 70.8 & & 84.4 & 67.7 & 57.6 \\
\hline
\end{tabular}

Source: IAK; Estonian Radio questionnaires 1966-2002.

to gain a collective reflection of what is going on, one needed to turn to humour to find the longed-for but missing kernel of truth.

In the height of the Soviet regime in the 1970s, but also in the following decades, humour was one of the main sources of the people's hopes and wishes, both in journalism and in public texts on the whole. Linguistic and cognitive 
diversity obviously served the purpose of alleviating the strict and rigid political reality (see Table 1 ).

We see from the data in Table 1 that the interests in different subjects differ throughout the years. After the 1990s when an open, active and independent wave takes over in the society and political reality, the former interest in music, humour, literature and theatre/cinema fades. At the same time, everyone becomes interested in the daily issues of the newly independent country - Estonian domestic issues, foreign affairs, jurisprudence and education are among the top subjects after 1990. So, the interest in a number of topics in the media falls for a longer period, only to rise again in the first years of the new century. Together with other topics, the significance of humour also rises again to a considerable degree only in the beginning of the $21^{\text {st }}$ century. Its task is to comment and reflect on a new system and social reality. Does this mean it has come full circle again?

It is evident from Table 1 that during the peak of the Soviet totalitarian system, there was a heightened interest in humour. The reasons for that were manifold. First of all, ideological repressions and total control in the newspapers/media left some free room only for humour, while all the other modes of self-expression were monitored most carefully. Humour with its multiplicity of meanings could escape this control to a small but significant degree. Secondly, due to a smaller control of humorous texts, humour was very carefully read and re-read by the audience; it was constantly interpreted and discussed. Compared to ideologically freer periods, humour at that time carried a very important role and was regarded as the source of truth. It was constantly examined for allusions and implications that would contain information about topics that could not have been addressed directly. Thirdly, when a person was not certain of the value of Soviet ideology, the first place indeed to go looking for proof about the doubts was humour. The world of allusions hidden beneath humour was wide and, depending on the sharpness or stupidity of the censor, could present a considerably different view about things than the official line of thinking would have liked.

The need and search for textual diversity was immense and every noncanonised nuance or detail in the ideologically censored media triggered a field of meanings, a cultural-political semiosis. 


\section{Contexts of Soviet humour}

There were only a few central newspapers in Soviet Estonia and these were printed in huge print-runs, which is why media consumption was relatively homogenous. Central newspapers were very widely read during Soviet times. Those newspapers were known for their humorous columns and humour-dedicated pages which were published several times a week. In addition to this, a humour journal called "Pikker" was published in Estonia.

We can make a distinction between two kinds of humour within the humorous discourse of the Soviet period: purposeful humour includes all newspapers' sections and broadcasts that were meant to be humorous; and in addition to this, voluntary humour was hidden between the lines, consisting of references, allusions, errors, metaphors, fables, humorous decodings of official texts, etc. Inserting humour disguised as everyday journalistic discourse was common among the more talented journalists in the 1980s. They threw in parodies of official style, or Moscow style, colourful epithets, revealing ambivalence, all of which played successfully on nuances of meaning and allowed for more emotionally and semantically charged texts.

Humour was an everyday phenomenon in Soviet times. The discussions all took place on the socio-cultural level and the political sphere was not a permitted topic for humorous communication. This nevertheless did not prevent the use of certain concepts as metaphors to discuss political issues. Transposing inflammable situations and characters into the less monitored daily discourse was a common practice. Censors from GLAVLIT ${ }^{3}$ worked against this with full force, controlling all public texts and signing permissions only if the content seemed safe and politically correct. At that time, Estonian radio and television broadcast aired humorous shows on weekends that were immensely popular among the audiences. However, the listeners were even more attentive while viewing or listening to serious broadcasts. They were attentive in order to catch the humour hidden between the lines. According to official documents from that time, censors made orders to get rid of metaphors that could carry multiple meanings such as "The most stubborn is the billy-goat - he thinks this territory is his property and wants to taste young apple trees. I usher it away. But after some time goes past he is back again, gnawing on the apple trees. He thinks the apples are his." (Estonian Radio, 1980) or "Wolverines have been recently spotted in Estonia. The wolverine is searching for food, having come from Pskov." (Nature alphabet book, 1980). There were instances during that period when the weather forecast in the Estonian Radio was also

3 GLAVLIT - The Central Board of Literary and Publishing Matters, was established on 6.6.1922, by a decree "to unite the establishments dealing with censorship". 
censored and its authors were punished for ambiguous content - for example, in the case when the newsreader added to the official text that "nothing good has ever come from the East".

Humour like this did not go unnoticed for the people and such "errors" were gratefully sought after. There was a sharp need to sever seeds from the chaff in the ideologically loaded public text.

A colourful example is the broadcast by the Estonian Radio titled "From border to border" (the journalists authoring this called it "From wall to wall"; it carried a rhyming feeling). It featured news from the Soviet Union and was aired on work days at 15:00 (see Table 2, section The news from USSR). By the end of the Soviet period it acquired a reputation which was quite comparative to any humorous show, and its popularity was very high (42\% of the population were regular listeners). The popularity was attained thanks to the choice of the material which consisted of seriously cited true facts and stories, but continued to actually portray the absurd and funny facts of everyday life in the Soviet Union. We can say that the stories belonged to the realm of humour without really being officially humorous. In the reports to GLAVLIT it was characterised as a broadcast with an aim of introducing and illustrating the daily life of other Soviet nations in the big friendly Soviet Union, i.e. as a broadcast with a general educative purpose (Lõhmus 2002).

Table 2. Size of media audiences 1985-1989 (\% of people following the programs).

\begin{tabular}{|l|c|c|c|c|c|c|}
\hline & Time & $\mathbf{1 9 8 5}$ & $\mathbf{1 9 8 6}$ & $\mathbf{1 9 8 7}$ & $\mathbf{1 9 8 8}$ & $\mathbf{1 9 8 9}$ \\
\hline Estonian Radio & & & & & & \\
\hline Morning news & $9: 00$ & 21 & 19 & 22 & 23 & 32 \\
\hline Daily news & $12: 00$ & 31 & 27 & 30 & 31 & 42 \\
\hline The news from USSR & $15: 00$ & 8 & 7 & 10 & 22 & 42 \\
\hline Foreign news & $18: 00$ & 14 & 14 & 16 & 14 & 17 \\
\hline Evening news & $20: 00$ & 14 & 13 & 12 & 14 & 26 \\
\hline Economic and political life & $14: 00$ & - & - & - & 17 & 27 \\
\hline Musical program & $21: 00$ & 6 & 7 & 8 & 6 & 7 \\
\hline Humour program (Sunday) & $11: 00$ & 44 & 45 & 45 & 45 & 45 \\
\hline
\end{tabular}

Source: IAK; Estonian Radio questionnaires 1985-1989.

The Estonian reader could not have a choice of mid-range or smaller publications, and this attracted a monolith non-segmented audience to most of the media.

Official humour in newspapers during the 1970s and early 1980s was mainly based on contiguity and micro-level jokes. It was forbidden to mock higher 
institutions in the political hierarchy or the political system itself, but joking about the simple people (including those working at lower positions like the janitor, or those coming from social peripheries like alcoholics) was allowed. If we look at the humorous content of Estonian newspapers in the first half of the 1970s (1970-1976) the dedicated humour pages in "Edasi" newspaper could be narrowed down to 14 categories. The most popular of these were daily topics and situation comedy, whereas categories like politics, sports, ideology and everything else stretching further from issues of everyday life were much rarer (Weinrauch et al. 1976: 41). Editors from that period have stressed that questions of nationality were strictly forbidden.

As a result, we can state that during Soviet times the possibilities of Estonian-language media consumption were limited. The audiences concentrated largely on a few cross-national daily publications, not having much choice in what to read or watch. Similarly, the consumption of "official" humour was limited to the bigger newspapers or programmes with closely controlled content emphasising mainly non-political content.

\section{Limitations of humour in Soviet Estonia}

In order to account for the requirements and limitations that were set for humour in Soviet Estonia, we should look at the humorous texts of this period and the nature of censorship applied to these texts.

Estonian Radio and Television were the first to air special humorous broadcasts during this period. At the end of the 1960s, the first shows were aired, starting with RAMETO and some weekend humour shows. In newspapers, the trend to have a dedicated humour page took off only in the 1970s. Before that there were no special editors for humour pages in the printed media; letter editors had the task to edit jokes during the $1950 \mathrm{~s}-60 \mathrm{~s}$, after that the assistant editors were to edit the episodic humorous content. After the $1960 \mathrm{~s}$, humour in written media developed into a distinct branch, and writers who specialised in writing humorous content emerged. From the 1970s onwards the jokes became more abstract.

A three-dimensional model can be used to represent the use of humour in Soviet Estonia. Different functions and roles were divided between different media channels and publications. The model resembles the general model of Soviet mythology (Lõhmus 2002: 63-64), which consists of three functional levels:

- general mythology consisting of the main ideology and myths of creation; 
- myths and actions meant to encourage achievement; these motivational texts took the form of practical examples and instructions, aiming to motivate people;

- $\quad$ everyday life of people produced suitable texts that were incorporated into the general mythology, these became rituals that fit into the general system.

Soviet Estonia had three main channels for humorous texts, divided into three different levels of the model: Estonian Radio and Estonian Television, culture weekly "Sirp ja Vasar", and a newspaper of localised distribution - city paper "Edasi" in Tartu (see Table 3):

Table 3. Three-dimensional model of laughter in Soviet Estonia (from the 1960s to the beginning of the 1990s).

\begin{tabular}{|l|l|l|}
\hline Level & Function & Channel \\
\hline $\begin{array}{l}\text { Ideological / } \\
\text { general mythology }\end{array}$ & $\begin{array}{l}\text { Representing ideas, main ide- } \\
\text { ology, contacts with external } \\
\text { world and the context of inter- } \\
\text { nal interpretations, generali- } \\
\text { sations from practice, macro- } \\
\text { level of the society }\end{array}$ & $\begin{array}{l}\text { "Sirp ja Vasar" } \\
\text { newspaper dedicated to } \\
\text { culture and education - }\end{array}$ \\
\hline $\begin{array}{l}\text { Collective reflec- } \\
\text { tion and collective } \\
\text { action }\end{array}$ & $\begin{array}{l}\text { Collective locality, cognition } \\
\text { and reflexivity; application } \\
\text { and control of ideologies; chan- } \\
\text { nelling and making sense of } \\
\text { action; meso-level of the soci- } \\
\text { ety }\end{array}$ & $\begin{array}{l}\text { Local newspaper "Eda- } \\
\text { sistributed all over Es- } \\
\text { tonia) }\end{array}$ \\
\hline Everyday life & $\begin{array}{l}\text { Reflecting on the details of } \\
\text { everyday life, life experiences, } \\
\text { micro-level of the society }\end{array}$ & $\begin{array}{l}\text { Entertainment shows } \\
\text { in the Estonian Radio/ } \\
\text { Estonian Television, } \\
\text { caricatures in "Edasi" }\end{array}$ \\
\hline
\end{tabular}

We will now take a look at the three dominant channels that were responsible for shaping public media discource and that also published or broadcasted humorous columns / sections / shows, etc.

Radio and television shows were collective and participatory: it was possible to take part in the recording of humorous broadcasts through acquiring free passes to attend public recordings, and even more than that - listening to and watching these shows had become a family / collective tradition at homes and 
it can be regarded as a popular pastime. Humour shows and programmes were aired as 1-2 hour sets, mostly on weekends. The shows were often a topic to talk about among friends and acquaintances. Therefore, radio and television had an important role in shaping public taste in culture and politics but also the way of talking about it. The creative staff at national broadcasting corporations had emerged from among the circles of reporters and editors active in the $1950 \mathrm{~s}$, and these teams became strong and recognised creative teams throughout the Soviet times until the end of the 1980s. The status of broadcast humour was very high, mostly due to the fact that it was always presented in a very earthly and grassroots manner - the shows were recorded in different locations all over Estonia (collective farms, clubs, collectives, etc.) which brought the jokes closer to the audience and at the same time this very environment was the inexhaustible source of humour itself. The reception of these radio and television shows was very emotional, because it was a collective habit, situative, and at the same time diachronic - the emotions were shaped and nurtured during the years that the show was broadcast.

The two examples of print media publishing humorous texts were "Sirp ja Vasar" and "Herilane" ('Wasp'), a humour page of the newspaper "Edasi". Due to the location of the editors' office which was side by side with the Tartu University main building, the editors and reporters of the newspaper were especially sensitive to the absurdities of Soviet life. The newspaper developed from one of the oldest newspapers in Estonia titled "Postimees", which in 1948 had to change its name to "Edasi" in order to have a more Soviet name and to detach itself from being associated with ideologically "foreign" groups. The humour column "Herilane" was popular among its readers and many writers who published there became widely known and accepted as important cultural figures. The weekly "Sirp ja Vasar" was a general newspaper concentrating on cultural and educational politics. It was started in 1940 and was especially designed to educate and shape the Soviet public. The publication was full of ideological and conceptual guidelines, but its last page developed into a humour page which - even without a name and concept - became a structurally distinct part of the paper. It primarly aimed at describing general cultural differences and philosophies from a humorous viewpoint. The humour page also contained quite formal information about caricature exhibitions, humour competitions and overviews of the same topic, while remaining quite general and philosophical in this mode.

In order to compare the nature of humorous content in these two publications (1955-1990), we can take a look at the analysis provided by Lauringson 1996 (Tables 4-8). 
Table 4. Professions of characters in "Sirp ja Vasar" and "Edasi" in 1955-1990; distribution of characters according to their areas of work (share of all characters). The professions of 1/ 3 of the characters could not be determined (Lauringson 1996: 49).

Culture Herilane Sirp ja Vasar

Politics 9 30

Manufacturing

6

12

Customer service, law enforcement

It is clear from this comparison that "Herilane" displays more characters who are active in manufacturing, whereas "Sirp ja Vasar" features characters who are active in the cultural and political domain.

Table 5. Distribution of characters between genres (share of all characters) (Lauringson 1996: 49).

$\begin{array}{cc}\text { Herilane } & \text { Sirp ja Vasar } \\ 28 & 56 \\ 2 & 6 \\ 38 & 20 \\ 32 & 18\end{array}$

"Herilane" published more long-format textual humour, whereas "Sirp ja Vasar" made more use of visual humour.

Table 6. Nationalities of characters (Lauringson 1996: 50).

Visual humour

Visual and textual humour combined

Textual long format

Textual short format

\section{Herilane}

Estonians

Foreigners

Soviet nations

Other
49

10

14

27
Sirp ja Vasar

39

28

18

15

"Herilane" from the Soviet period depicts more Estonian local characters, whereas "Sirp ja Vasar" shows a more equal distribution between the categories.

People with distinct hobbies are safe targets. It was easy to take texts with this topic over from foreign publications - copyright laws did not apply in the USSR and everything that was interesting and could fit into the ideological system was translated and published. As a side-note, if the domain of occupa- 
Table 7. Characteristics that are made fun of (Lauringson 1996: 52).

\begin{tabular}{|c|c|c|c|c|c|}
\hline \multicolumn{3}{|l|}{ Herilane } & \multicolumn{3}{|c|}{ Sirp ja Vasar } \\
\hline 1. Stupid & $17 \%$ & hobbies & 1. Stupid & $19 \%$ & $\begin{array}{l}\text { manufactur- } \\
\text { ing }\end{array}$ \\
\hline $\begin{array}{l}\text { 2. Sexual dys- } \\
\text { functions }\end{array}$ & $9 \%$ & culture & 2. Lowbrow & $8 \%$ & culture \\
\hline 3. Silly, weird & $9 \%$ & $\begin{array}{l}\text { ideology, sci- } \\
\text { ence }\end{array}$ & 3. Shy & $7 \%$ & $\begin{array}{l}\text { manufactur- } \\
\text { ing }\end{array}$ \\
\hline $\begin{array}{l}\text { 4. Greedy, } \\
\text { stingy }\end{array}$ & $7 \%$ & $\begin{array}{l}\text { ideology, sci- } \\
\text { ence }\end{array}$ & 4. Amiable & $7 \%$ & culture \\
\hline $\begin{array}{l}\text { 5. Clumsy, inef- } \\
\text { ficient }\end{array}$ & $7 \%$ & $\begin{array}{l}\text { manufactur- } \\
\text { ing (urban) }\end{array}$ & 5. Arrogant & $7 \%$ & $\begin{array}{l}\text { politics, cul- } \\
\text { ture }\end{array}$ \\
\hline 6. Cowardly & $7 \%$ & $\begin{array}{l}\text { politics, man- } \\
\text { agement }\end{array}$ & $\begin{array}{l}\text { 6. Sexual dys- } \\
\text { functions }\end{array}$ & $6 \%$ & not defined \\
\hline 7. Arrogant & $6 \%$ & culture & 7. Silly, weird & $6 \%$ & hobbies \\
\hline 8. Lazy & $6 \%$ & $\begin{array}{l}\text { manufactur- } \\
\text { ing (rural) }\end{array}$ & $\begin{array}{l}\text { 8. Greedy, } \\
\text { stingy }\end{array}$ & $6 \%$ & service \\
\hline 9. Lowbrow & $6 \%$ & culture & 9. Evil & $6 \%$ & politics \\
\hline 10. Cunning, sly & $5 \%$ & science & 10.Cunning, sly & $5 \%$ & hobbies \\
\hline 11. Lying & $5 \%$ & $\begin{array}{l}\text { manufactur- } \\
\text { ing }\end{array}$ & 11. Pedantic & $5 \%$ & hobbies \\
\hline 12. Evil & $5 \%$ & public office & $\begin{array}{l}\text { 12. Clumsy, in- } \\
\text { efficient }\end{array}$ & $4 \%$ & hobbies \\
\hline
\end{tabular}

tion could not be assigned, the character was most likely to be Estonian. Other nation's vocational domains were more clearly described in the humorous texts. Characters involved in the cultural domain are referred to as the least stupid. At the same time, this is the group (e.g. popular musicians) accused most of banal and lowbrow behaviour - vain dandies producing empty texts that they call art. A lack of cultural behaviour does not go unnoticed with the creators of humorous material. Sexual dysfunctions were marked in the material in cases where artists, for example, were represented as hypersexual (Lauringson 1996:53).

We can see from Lauringson's analysis of the functions of Soviet humour in journalism that humour carried an important role in setting and maintaining norms and regulations, and it also fulfilled a social function. By collectively consuming humorous texts in the media, the audience could be influenced and shaped. The local differences also had an effect: "Herilane" was more provocative, brave and concrete, whereas the cultural weekly "Sirp ja Vasar" was more abstract and general. 
Table 8. Comparison of the functions of humour in Sirp ja Vasar and Herilane (share of functions; Lauringson 1996: 60).

\begin{tabular}{|c|c|c|c|c|c|}
\hline \multicolumn{3}{|c|}{ Herilane } & \multicolumn{3}{|c|}{ Sirp ja Vasar } \\
\hline $\begin{array}{l}\text { 1. Passing } \\
\text { judgement }\end{array}$ & 66 & $\begin{array}{l}\text { Law enforce- } \\
\text { ment, politics }\end{array}$ & 1. Amusement & $77 \%$ & $\begin{array}{l}\text { hobbies, } \\
\text { undefined }\end{array}$ \\
\hline 2.Amusement & 64 & $\begin{array}{l}\text { hobbies, law en- } \\
\text { forcement }\end{array}$ & $\begin{array}{l}\text { 2. Passing } \\
\text { judgement }\end{array}$ & $69 \%$ & $\begin{array}{l}\text { cultural poli- } \\
\text { tics, ideology }\end{array}$ \\
\hline $\begin{array}{l}\text { 3. Expression } \\
\text { of wittiness }\end{array}$ & 46 & hobbies, politics & $\begin{array}{l}\text { 3. Expression } \\
\text { of wittiness }\end{array}$ & $54 \%$ & $\begin{array}{l}\text { manufacturing, } \\
\text { undefined }\end{array}$ \\
\hline $\begin{array}{l}\text { 4. Provoca- } \\
\text { tive }\end{array}$ & 34 & manufacturing & 4. Informing & $28 \%$ & $\begin{array}{l}\text { politics, } \\
\text { ideology }\end{array}$ \\
\hline $\begin{array}{l}\text { 5. Regulatory } \\
\text { function }\end{array}$ & 31 & $\begin{array}{l}\text { manufacturing, } \\
\text { services, public } \\
\text { discipline }\end{array}$ & $\begin{array}{l}\text { 5. Human } \\
\text { values }\end{array}$ & $23 \%$ & $\begin{array}{l}\text { undefined, } \\
\text { public } \\
\text { discipline }\end{array}$ \\
\hline 6. Informing & 25 & $\begin{array}{l}\text { manufacturing, } \\
\text { services, public } \\
\text { discipline }\end{array}$ & 6. Provocative & $23 \%$ & $\begin{array}{l}\text { political } \\
\text { ideology }\end{array}$ \\
\hline $\begin{array}{l}\text { 7. Turning } \\
\text { attention }\end{array}$ & 17 & $\begin{array}{l}\text { manufacturing, } \\
\text { services, } \\
\text { discipline }\end{array}$ & $\begin{array}{l}\text { 7. Protecting } \\
\text { dominant } \\
\text { culture }\end{array}$ & $15 \%$ & undefined \\
\hline $\begin{array}{l}\text { 8. Human } \\
\text { values }\end{array}$ & 17 & $\begin{array}{l}\text { manufacturing, } \\
\text { undefined, } \\
\text { culture }\end{array}$ & $\begin{array}{l}\text { 8. Absurd } \\
\text { humour }\end{array}$ & $14 \%$ & $\begin{array}{l}\text { hobbies, } \\
\text { manufacturing }\end{array}$ \\
\hline $\begin{array}{l}\text { 9. Hidden in- } \\
\text { formation }\end{array}$ & 13 & Politics, ideology & $\begin{array}{l}\text { 9. Regulatory } \\
\text { function }\end{array}$ & $14 \%$ & $\begin{array}{l}\text { manufacturing, } \\
\text { culture }\end{array}$ \\
\hline $\begin{array}{l}\text { 10. Protect- } \\
\text { ing dominant } \\
\text { culture }\end{array}$ & 12 & $\begin{array}{l}\text { undefined, } \\
\text { culture }\end{array}$ & 10. Informing & $12 \%$ & $\begin{array}{l}\text { culture, } \\
\text { ideological } \\
\text { journalism }\end{array}$ \\
\hline
\end{tabular}

I will now turn to some examples and details in the development of Estonian humour in the totalitarian period.

The early 1950s is a period when humour cautiously stepped into the field of public discourse. Often "a joke" was a piece of criticism towards an institution or a person, waiting for a reply. The critique was very specific and directed, and nowadays it would be very hard to define it as a joke. Ideology officials sent "critical signals" to editors who were supposed to create jokes on these topics, mainly meant to highlight negative characters. The dominant topics were manufacturing, everyday life and alcoholism, most frequent target groups were bureaucrats, loafers, and drunkards (see also Laineste 2012 about the 
topics in Soviet estrada). The 1950s were characterised by an increase in daily life topics and using humour for eliminating drawbacks from the society. People expected humour to criticise and turn attention to shortcomings. Humour column editors from the 1950s have recalled that the Central committee of the Estonian Communist Party closely observed their columns and suggested they should concentrate on making positive criticism. Jokes concerning nations were a taboo (Trull 1996). "Sirp ja Vasar" published a story by J. Smuul in 1955 called "Strange adventures of Muhu men during the jubilee singing festival in Tallinn", which became a valued specimen of contemporary humorous fiction. The dominant topics for mockery in "Sirp ja Vasar" were new trends in music or clothing, which was the beginning of the trend to make fun of lifestyles. Some humorous texts were translated from the Russian humour publication "Krokodil".

From 1955 onwards, political humour developed quickly and was mostly channelled into the journal "Pikker", daily newspaper "Edasi", and cultural weekly "Sirp ja Vasar". The development of the genre paved the way for the absurd and black humour in the 1970s. Professional journalists/humorists emerged.

The 1960s experienced a considerable addition to the body of young authors of humorous texts. In 1962, the Estonian Journalist Union's satire section was created and the level of professionalism rose. The atmosphere loosened up a little and the collective creation of humorous texts became more frequent. Many writers followed the example set by humorous texts of the 1930s. "Herilane" from that period contains mostly criticism on everyday matters, leaving names unmentioned. We can observe the rise in jokes focusing on entertainment, but also in humour based on linguistic puns. Some topics are prescribed by the censors: for example, "Sirp ja Vasar" frequently mocks capitalists and their religion. Among the greatest taboos were the communist party, national security office, Soviet domestic and foreign affairs, and party leaders.

The 1970s are now regarded as the heyday of totalitarian humour. Predominant jokes were based on absurdity, which allusively criticise the system. Jokes as a genre were viewed as antagonistic and creating counterculture. It was believed to equip people with new (and dangerous) tastes in humour. Humour published in "Herilane" developed boldly: a typical example of new developments were Andres Ader's “Alice” jokes, which seemingly dissected relationships between men and women, but the style of which was rather similar to Western comic strips. It was very new and seemed quite alien at first. "Sirp ja Vasar" was more restrained, and their targets were local culture activists mocked through humorous texts and caricatures. 
The 1980s are recognised for their absurd and joke-loving atmosphere. The "Edasi" editorial office where "Herilane" was created also functioned as a club for similar-minded people. Dominant features were absurd humour, puns, and intellectual humour. "Edasi" began to play the leading role in the Estonian perestroika era even before the era officially started. This was fostered by close cooperation with the university. On the other hand, a lot of pressure was put on "Sirp ja Vasar" as well to deliver high-quality humorous content. Censorship was severe; a lot of texts were turned down. For example, the editor-in-chief did not agree to publish the translated aphorisms by Karel Čapek, titled "Our times". However there was also some positive development: "Herilane" and "Sirp ja Vasar" started a serial "relay-story" between the two papers, a critique of the Stalin era, describing the shortcomings of the totalitarian system. This encouraged the "Sirp ja Vasar" editors to become bolder and choose more critical discourse in their columns. New humour societies were created, such as the Lokaallabor ('Local Lab') and Hans Leberechti Selts ('Hans Leberecht Society') (1989). It was not permitted to undermine the leaders and the system on the whole, but mocking politics was already allowed. This was due to the more relaxed atmosphere, which was started at the plenary meeting of creative unions in 1988. Just a year before the moods were still quite different: the editor-in-chief of "Sirp ja Vasar" has written in his memoires that in 1987 when the legendary caricature Sitta kah ('Just shit') (see the analysis below) was published in the newspaper, the Communist Party Central Committee discussed his case and imposed a penalty. "It left an unforgettable impression [...] It was a total farce." (Rattus 1995).

In the year 1990, GLAVLIT finished its work in Soviet Estonia. This was accompanied by a general loosening up of public texts and journalism. The range of available topics became wider, jokes became overtly political and authors of humorous texts were not afraid to criticise the mistakes of contemporary Estonian politicians. A popular trend in the 1990s humour production was publishing stories from the totalitarian period. Lembit Remmelgas created a set of stories titled "Real stories aka anecdotes", which reflected on the life and deeds of several totalitarian politicians, starting from Stalin. The travesty of culture became another common feature of the humorous texts of that time. Parodies of classical pieces of Estonian poetry were published (written by Mart Juur). This was part of the more general tendency to paraphrase quotations known from the socialist past (see also Laineste 2009). The thematic page in the "Sirp ja Vasar" jubilee edition is a good example of this. It was titled “"Sirp ja Vasar" - the mind, music, art, literature, honour and conscience of our times". Jokes about politics and ideology became a part of everyday life and have remained popular until recent years. 


\section{Humour or silence? An analysis of the cartoon Sitta kah (Priit Pärn 1987)}

Expressing emotions through humour is better than the alternative of silencing the incongruous fact or concept altogether. In 1965 there was a fire in the main building of the University of Tartu. Journalists were aware of the fact, but news about it was allowed in the media only three days after the event - and then the news text announced that the restoration works have been started, but did not mention the fire itself (Uus 2005). Only as a result of a very fine differentiation could such examples of serious events be translated into the language of humour. This can be seen as an example of dark black humour when journalists, under the pressure of censorship, keep absolute silence about a catastrophe involving a national symbol like the University of Tartu.

Every spring a cross-national cartoon competition was held by the weekly newspaper "Sirp ja Vasar". It was known for drawing together the brightest talents, as a parade of professionalism. The competition was also perceived as a request to achieve the highest level of artistry by drawing the essence of the message from the past year. It challenged all active professionals of that period. As part of the tradition, credit was given to cartoons which touched an important question from the realm of culture, society or identity, but approaching it from a novel angle. The caricaturists who were considered the cream of cultural intelligence shared a common concern about Estonia's future existence. A hot topic in 1987 was the preparation of a new phosphorus field for mining in Eastern Estonia. This subject was relatively classified information and not

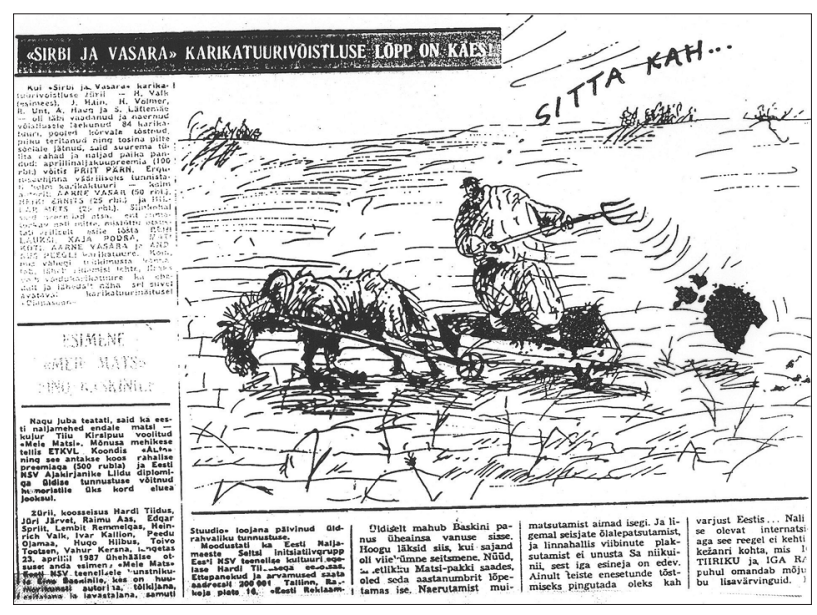

Figure 1. Cartoon Just shit (Priit Pärn, 8.5.1987, Estonian cultural weekly "Sirp ja Vasar"). 
openly debated in the media. At the same time, people were alarmed and stood against it on the whole. Estonian cultural weekly "Sirp ja Vasar" published a cartoon by Priit Pärn Just shit, the winner of the cartoon competition. In this cartoon (see Figure 1), the cartoonist shows a peasant shovelling manure in his field. The shape of the portion of manure being strewn resembles that of Estonia. This picture depicts the situation where the interests of the political and economical elite from Moscow contradict the local preferences: Moscow was interested in producing field fertilisers in Estonia, whereas Estonians were afraid of unsolvable social and ecological problems (polluted ground water, etc.). From an interview with Priit Pärn (Lõhmus 2004) it is evident that he created the cartoon out of anxiety about the environment, country and state. Thus the caricature was a mental summary of a long-term process that had forced foreign ideology on Estonia on the one hand, and the cultural elite's counter-reaction to that oppression on the other.

Using the terms of Bakhtin (1965/1993), the end of the totalitarian carnival was near. Facts found their way into journalism. The cartoon contest in 1987 bore remarkable similarities to the end of the carnival as Bakhtin described it. The end of the carnival period was a time for everyone to redefine and restore the systems of meaning, but without the carnival the official semantic fields would collapse - the carnival acted as a safety valve for venting anti-regime feelings.

Rigor mortis and the breakdown of the totalitarian system followed the year 1987, but the representatives of the totalitarian system still managed to pursue and punish the editor-in-chief of the publication where the cartoons were published, Ilmar Rattus. We might say that Just shit is the most famous cartoon in the Estonian cartoon history. This was made possible by two factors: professional humour writing had reached its heyday, and the audience was extremely attentive to any novel allusions and references (see also Table 1).

The phenomenon itself, the Estonian cartoon, plays an important role in the development of Estonian society - it has helped to carry through the difficult transformation from a powerless periphery of a totalitarian state into an independent state, and from the cultural elite into a political elite. The emergence of the political activists in the public sphere made it possible to pave the way to regaining independence in 1991. 


\section{Conclusion: Soviet Estonian humour in the media}

There were two kinds of editors working in the totalitarian system. The first group consisted of more insecure editors who felt deeply suppressed by the rules. The more talented half enjoyed their ability to write between the lines. The rules and regulations of censorship were unequivocal and the censors had a hard time "fixing" jokes that were created by authors with a better sense of humour than themselves - or even to find a pretext for it, for that matter. The possibility to deliver meaning in between the lines was something that brought excitement into the process. In comparison, contemporary journalists have complained about the lack of meaning in joke-making and -consuming: "Now, when we can say anything, there is no real interest in it for the readers and authors alike" (Hanson 1996). A typical pastime for a talented journalist was to use words and create puns in a way that the censors would not see the double meaning but the people would instantly "get it". The slang term for this kind of entertainment was "dancing on the razor's edge", and it was an everyday challenge for the authors. On the other hand, we can say that these suppressions formed the basis for the multiplicity of genres, fostered creativity in finding the means to sneak past the censors. The value of censorship in cultivating the diversity and quality of humorous genres can be seen nowadays where a lack of suppression has resulted in simpler and simpler forms of humour. Texts are void of playfulness and display no sensitivity for puns.

Humour is the Achilles' heel of the totalitarian regime. The semiotic system of humour is especially ambivalent, because its essential message could be true in the reflection of reality, but according to the norms of the totalitarian regime it is considered a deviant phenomenon. The attitude towards humour was very complicated in the totalitarian state. Seemingly simple questions emerged: What is humour? What could be laughed at? Where can you tell jokes? Who can tell jokes? All these had complicated answers in the totalitarian society.

The totalitarian regime can be characterised by a situation that could be called a general anticipation for meanings. The textual field as a field of meanings is extremely actualised due to the existing system of canonical official texts. In the actualised textual field, all its elements have a potentiality for change, above all on the mental/textual level, but the Soviet system's textual field worked as a structural element for the system. In this sense, the functionality of texts and functionality of elements of the texts acted as a controlled field of meanings. In the actualised texts all the meanings were controlled and designed carefully. Nevertheless, talented journalists had a high level of competence to 
create and produce ambivalent texts and jokes that would be acceptable in the eyes of the censors, but were read as an example of resistance by their audience.

Humour published as a part of public texts (in the media) is known for turning attention to the negative heroes or phenomena of the society. Humour reflects on the unofficial, structurally lower levels or sidetracks of the social reality. It uses linguistic, reflexive and constructivist means to transform everyday phenomena into humorous texts, finding broader meanings and images in its subject matter. The Soviet society as a whole became very sensitive towards puns in particular, and language in general. Humour had a big role in developing this sensitivity.

\section{References}

Bakhtin, Mikhail 1965/1993 [1941]. Rabelais and his world. Transl. Hélène Iswolsky. Bloomington: Indiana University Press.

Hanson, R. 1996. Naljanurga toimetajad vastavad. [Humour section editors answer.] In: E. Lauringson (interviewer) Herilase ning Sirbi ja Vasara naljanurga võrdlus aastatest 1955-1990. [Comparisons of humour sections in Herilane and Sirp ja Vasar 1955-1990.] Append. 9, p. 118.

$I A K=$ Information Centre of Estonian Radio and TV Committee, annual research reports Info Bulletin. ESTA. [Database of Estonian social scienes.] University of Tartu.

Laineste, Liisi 2009. Conclusion. In: A. Krikmann \& L. Laineste. Permitted laughter: Socialist, post-socialist and never-socialist humour. ELM Scholarly Press: Tartu, pp. 371-406.

Laineste, Liisi 2012. Stand-up in Estonia: From Soviet estrada to Comedy Estonia. In: L. Laineste \& D. Brzozowska \& W. Chłopicki (eds.) Estonia and Poland. Creativity and tradition in cultural communication, Vol. 1. Tartu: ELM Scholarly Press, pp. 73-90.

Lauringson, Ester 1996. Herilase ning Sirbi ja Vasara naljanurga võrdlus aastatest 1955-1990. [Comparisons of humour sections in Herilane and Sirp ja Vasar 1955-1990.] Manuscript.

Lõhmus, Maarja 2002. Transformation of public text in totalitarian system. A sociosemiotic study of Soviet censorship practices in Estonian Radio in the 1980s. Tartu, Turku: Tartu University Press. Monograph.

Lõhmus, Maarja 2004. An effect of meaning-breaker: Analysis of the cartoon Just shit. Semiotica 150, pp. 257-282.

Rattus, Ilmar 1995. Vastab peatoimetaja. [Editor-in-chief answers.] Kultuurileht, 6 Oct, pp. 6-7. 


\section{Maarja Lõhmus}

Trull, Boris 1996. Naljanurga toimetajad vastavad. [Humour section editors answer.] In: E. Lauringson (interviewer) Herilase ning Sirbi ja Vasara naljanurga võrdlus aastatest 1955-1990. [Comparisons of humour sections in Herilane and Sirp ja Vasar 1955-1990.] Append. 9, p. 116.

Uus, Sulev 2005. Oled kuulnud, et ülikool põles? [Have you heard that the University was on fire?] Postimees, 29 Dec.

Weinrauch, Epp \& Vihalemm, Peeter \& Lauristin, Marju \& Napa, Aime \& Palmaru, Tiia 1976. Huumori ja satiiri vastuvõtt Edasi lugejaskonna gruppide poolt. Töölised Edasi lugejana. [Reception of humour and satire by the readers of Edasi. Workers as an auditorium.] (Final report.) Tartu: TÜ AKI. Manuscript. 